\title{
SOSIALISASI DATABASE RELASIONAL E-DOCUMENT BKD dan LKD DOSEN FLATFORM MICROSOFT ACCESS PADA UNIVERSITAS DHARMA ANDALAS PADANG
}

\author{
Idwar $^{1}$, Yofina Mulyati ${ }^{2}$, Prima Yulianti ${ }^{3}$ \\ ${ }^{1,2,3}$ FEB Universitas Dharma Andalas (UNIDHA) Padang \\ Email : Idwar68@unidha.ac.id
}

\begin{abstract}
Abstrak
Sebagai seorang dosen mempunyai tanggung jawab untuk melaksanakan Tri Dharma Perguruan Tinggi dan wajib membuat laporan kinerja pada BKD dan LKD secara manual yang kemudian dilakukan dengan komputerisasi, nanum masih banyak kendala dalam pengarsipan, maka disini penulis membuat sosialisasi agar easy to documentation arsip dosen secara elektronik dimasa pandemic covid-19, untuk ini penulis membuat implementasi database e-document BKD dan LKD dengan aplikasi Microsoft Access.

Tujuan pengabdian ini untuk membantu : 1)Dosen Mengarsipkan kegiatan Tri Dharma Perguruan Tinggi secara perorangan. 2). Mendigitalisasi document dalam bentuk files. 3) Mendatabase file-file BKD dan LKD dosen pada tingkat Universitas persemester Gasal/Genap.

Metode yang dirancang dalam kegiatan ini berupa : 1) Mencreate table-tabel database relasional . 2) Mencreate Form-form input. 3) MenQuerykan relasi-relasi table sebagai kebutuhan informasi BKD dan LKD.

Adapun hasil dari kegiatan ini diharapkan dosen mampu mengunakan flatform Microsoft Access untuk edocument BKD dan LKD, hasil kegiatan pengabdian ini : 1) Mensosialisasikan Database Relasional. 2)Mendemokan aplikasi e-document untuk input data-data dosen. 3) Target luaran berupa : software Aplikasi, Paten/Haki software dan journal.
\end{abstract}

Kata Kunci : database relasional, e-document, BKD dan LKD

\section{PENDAHULUAN}

\section{Analisa situasi}

Seorang dosen baik di Perguruan Tinggi Negeri atau Swasta, harus melakukan Tri Dharma Perguruan Tinggi, yang mana kesemua tugas tersebut terdokumentasi dalam bentuk sebuah database. Database dosen pun juga sudah terintegrasi dalam sebuah big data yang berada pada sebuah server perguruan tinggi se Indonesia yaitu berada dalam sebuah database terpusat dengan nama PDDIKTI/SISTER. Seorang dosen wajib melalui proses sertifikasi dosen (SERDOS), dan setelah mempunyai sertifikat itu, maka kewajiban dosen memberikan laporannya yang tertuang dalam database LKD dan BKD menggunakan aplikasi Microsoft Access. Selesai melakukan pengajaran, penelitian, pengadian serta penunjang dalam satu 
semester maka dosen wajib melaporkan hasil kegiatannya tersebut pada aplikasi database. Ada pun bentuk form yang dilakukan secara manual seperti terlihat pada gambar 1 , berupa output menu utama dibawah ini :

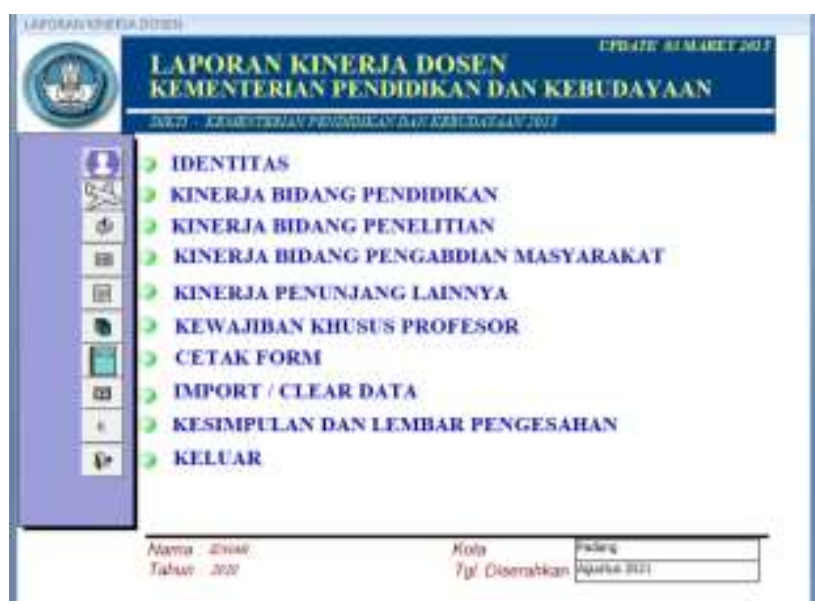

\section{Gambar 1. Output Menu Utama}

Dari tampilan menu diatas maka para dosen melanjutkan pekerjaan menginput data serta upload dokumen sesuai kebutuhan seperti contoh pada form berikut ini pada gambar 2 dibawah ini :

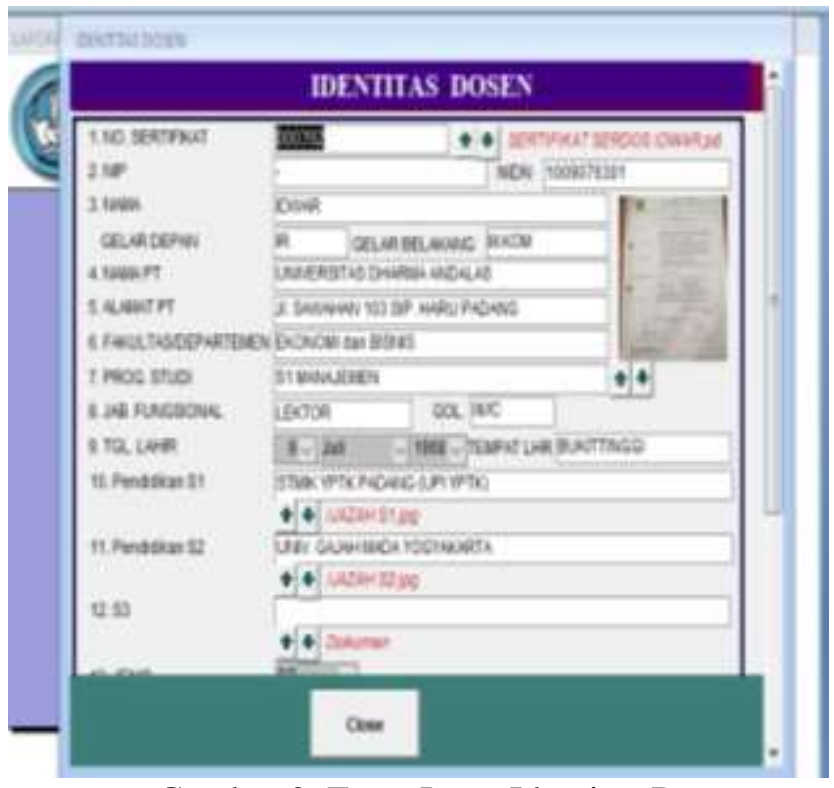

Gambar 2. Form Input Identitas Dosen

Pada form diatas ada penginputan data dan upload dokumen, yang mana setelah pindah ke computer/ laptop lain maka upload dokumen tidak terbawa atau terekam dan form tersebut, sehingga dari masalah diatas dibuatlah sebuah desain database relasional yang dapat merekam dokumen yang tidak perlu dicopikan lagi semua dokumen lagi dibutuhkan dalam database tersebut. E-Document BKD membantu pengarsipan database dokumen dosen yang dibutuhkan untuk penginputan/arsip dokumen dibutuhkan kapan saja.

\section{Permasalahan yang dihadapi}

Database dalam penginputan LKD dan BKD dosen masih menggunakan flatform Microsoft Access, dimana dosen menginput data dan dokumen setiap akhir semester gasal dan genap. Permasalahan yang dihadapi oleh dosen jika file master isian LKD dan BKD dipindahkan/dicopikan ke tempat penyimpan lain maka file dokumen tidak terbawa, dan dokumen yang diinput masih dalam bentuk file yang kapasitas terbatas. Maka penulis mencoba mengatasi masalah ini dengan membangun sebuah database relational yang dapat mengatasi hal ini yang diberi nama E-Documen LKD dan BKD. Pada database yang dibentuk bisa merekam dokumen dalam bentuk record dan mengetikkan link URL dokumen.

\section{Tujuan}

Memberikan sosialisasi E-Document LKD dan BKD kepada seluruh dosen yang ada dilingkungan kampus Universitas Dharma Andalas (UNIDHA) Padang. Dimana hasil ini dapat membantu dosen untuk 1). Mengarsipkan data/dokumen. 2). Membantu dalam perekaman dokumen yang utuh. 3). Dapat update database sesuai kebutuhan. 4). Dapat menyimpan dokumen dalam alamat URL baik itu dalam bentuk google drive atau bit.ly

\section{METODE}

Dalam melakukan desain database dan aplikasi serta implementasi E-Document ini penulis berlandaskan metode dan teori yang didasari atas pakar database Bernama EF Codd, 1990. Penulis mengimplementasi metode database realational (relasi database). 


\section{1) Model data konseptual terdiri 2 macam}

1.1)Object base data model (Model data berbasis object). Menjelaskan hubungan logik antar data dalam suatu database berdasar obyek datanya.

Misal : Entity Relationship (E-R), Semantik, Object Oriented.

1.2)Record Base data Model (Model Data berbasis Record) Menjelaskan hubungan logik antar data berdasar record digunakan untuk menguraikan implementasi sistem database.

Misal : Relational, Hirarki, Jaringan.

\section{Penulis mengunakan metode Relational dengan E-R Model :}

1).Entity Relationship Model Dikenalkan oleh Chen (1976). 2).Berdasarkan anggapan bahwa dunia nyata terdiri dari koleksi obyek-obyek dasar yang dinamakan entitas (Entity) serta hubungan (Relationship) antara entitas - entitas tersebut. 3).Tak Bergantung DBMS dan platform perangkat keras digunakan untuk : 4).Mengembangkan Model K onseptual. 5).Menjelaskan Struktur Basis Data. 6).Memberikan gambaran pada pengguna terhadap data.

2) Tiga Komponen Penting dalam Model E-R yaitu : Entity, Atribut dan Relasi

ENTITY / ENTITAS : Obyek di dunia nyata yang dapat dibedakan dengan obyek yang lainnya. Set Entity / Himpunan Entitas : Kumpulan Entity yang serupa. Set Entity dapat berupa Fisik : Perguruan Tinggi, Dosen, Kinerja Pendidikan, dan Kinerja Penelitian.

Konsep/Logik: Mengajar, Mata Kuliah, Kesimpulan BKD dan LKD.

Simbol Entity :
empat)

Contoh Entity: Idwar, Yofina, Prima, Yentisna, dimodelkan sebagai Dosen

\section{ATRIBUT}

Ciri atau karakteristik yang bermakna untuk mendeskripsikan entitas. Bertujuan untuk membedakan obyek-obyek di dalam entity karakteristik yang bermakna dan tidak bermakna, contoh untuk entity Dosen maka : bermakna : NIDN, Nama_dosen, Alamat, dst

tidak bermakna : Tinggi_badan, berat badan, Tinggi_badan dan berat_badan menjadi karakteristik yang bermakna bagi entity Lain. Simbol atribut : elips dan dihubungkan dengan entity melalui garis. Lihat gambar 3.

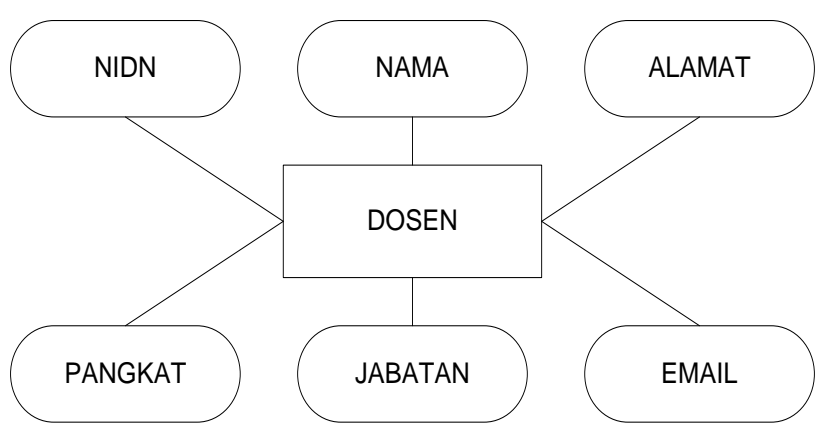

Gambar 3. Contoh atribut dengan Entity

\section{JENIS-JENIS ATRIBUT :}

1) Atribut Sederhana

Atribut yang disusun hanya dari satu komponen tunggal dengan keberadaan bebas. Atribut sederhana tak dapat dibagi lagi. atribut atomic. Misal : nama, jenis_kelamin

2) Atribut Komposit terdiri dari :

2.1)Atribut Komposit yaitu :

Atribut yang disusun dari banyak komponen yang masing-masing keberadaannya bebas. Atribut dapat dipecah menjadi komponen yang lebih kecil yang keberadaannya bebas contoh : alamat jalan, no_rumah, RT, RW, dst

2.2)Atribut Tunggal yaitu :

Mengandung hanya satu nilai. Bisa terdiri dari atribut sederhana atau atribut komposit contoh : NIDN, NIK, Agama.

Keterangan :Seorang Dosen hanya punya 1

NIDN, atau 1 Agama

2.3) Atribut Bernilai Banyak / Jamak.

Teknologi Informasi dan Komunikasi 
Atribut yang mengandung banyak nilai. Contoh: hobby, skill, nomor_mobile.

Keterangan : Seorang dosen bisa memiliki banyak hobby atau lebih dari 1 nomor_mobile

\section{4) Atribut turunan}

Atribut yang mengandung nilai dimana nilai tersebut bisa diperoleh dari hasil kalkulasi atau penerapan algoritma ke atribut lain. contoh : atribut umur bisa diperoleh dari atribut tanggal_lahir

Domain Atribut adalah :

1)Himpunan nilai yang diberikan ke suatu atribut. 2). Termasuk diantaranya : tipe data, panjang, konstrain, format dll. 3).Atribut yang berbeda boleh mempunyai domain yang sama

Key (Kunci) adalah :

1).Himpunan dari satu atau lebih atribut yang digunakan untuk membedakan antara satu entity dengan entity yang lain. 2).Harus unik dan tidak boleh kosong. 3).Superkey, Candidate key, primary key. 4).Primary Key : Candidate key yang dipilih untuk identifikasi entitas pada himpunan entitas. Digambarkan dengan menambah garis bawah (NIDN) lihat gambar 4.

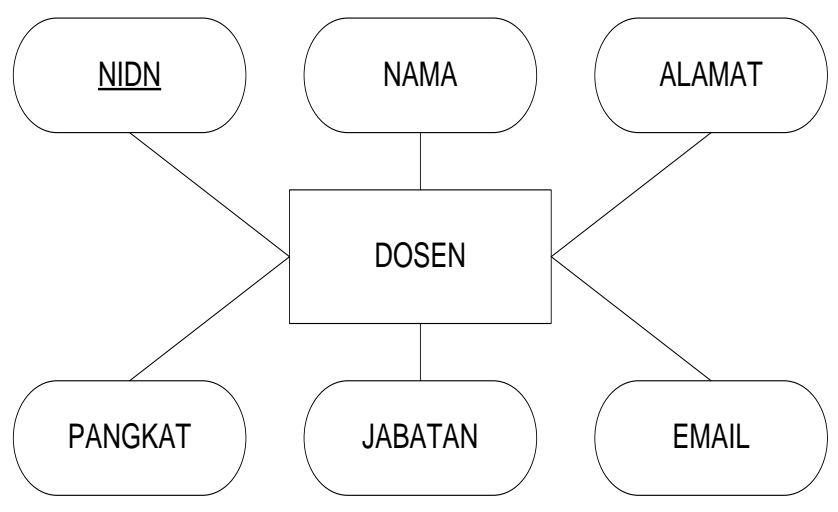

Gambar 4. Contoh Primary Key dan atribut
Himpunan antara satu himpunan entitas dengan himpunan entitas yang lain. Dilambangkan dengan simbol diamond yang didalamnya terdapat kata kerja/ kata hubung. Lihat gambar 5. Dibawah ini

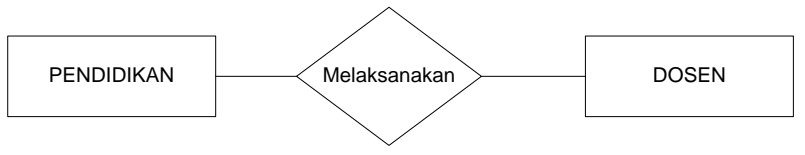

Gambar 5. Contoh Relasi dengan simbolnya

Atribut Hubungan / atribut relasi :

Uraian tentang suatu hubungan, Berguna untuk penjelaskan suatu hubungan, Jika atribut hubungan cukup banyak maka perlu dipertimbangkan untuk menjadi entity baru. Contoh lihat gambar 6 dibawah ini :

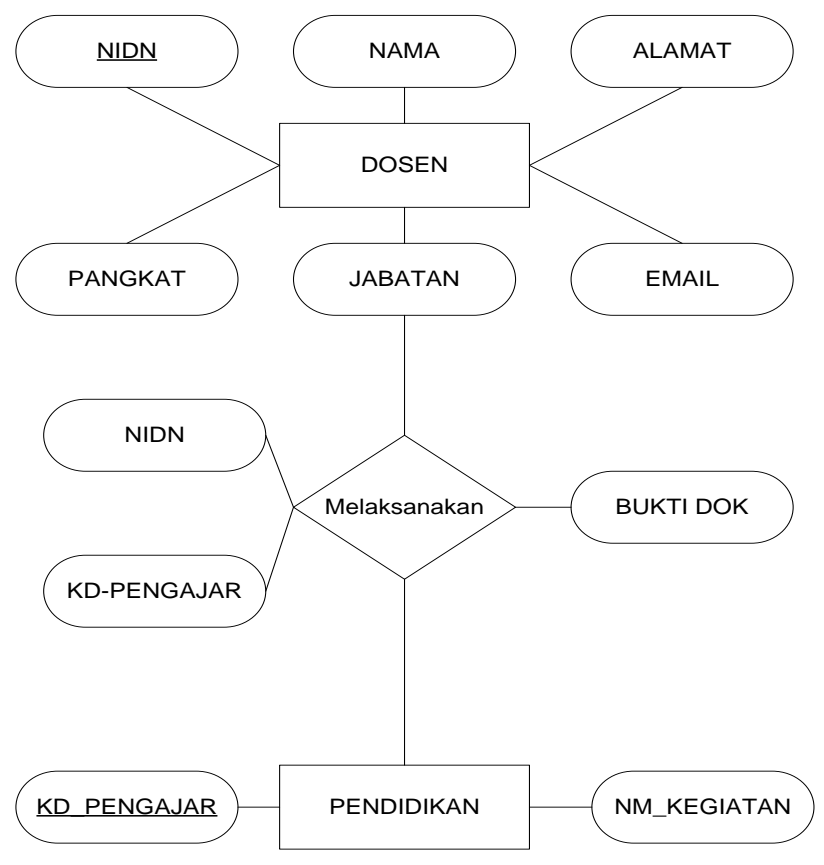

Gambar 6. Contoh relasi yang dilengkapi atribut

\section{HASIL DAN PEMBAHASAN}

Dalam sosialisasi ini, penulis lansung mendemo/praktikum dengan melalui zoom meeting karena situasi Pandemi COVID 19, dimana para dosen mengunakan computer/Laptop, bapak/ibuk dosen juga bisa melihat link youtube https://youtu.be/o02b07Mh118 berulang-ulang jika ada yang masih kurang paham dalam praktikum/ 
menginput data/dokumennya. Terlihat rekaman gambar 7 dari zoom meeting dibawah ini :

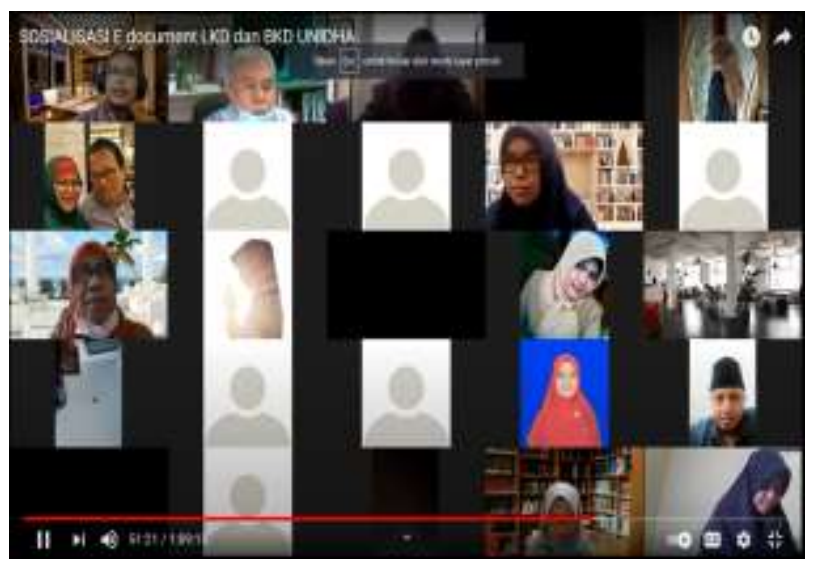

Gambar 7. Zoom Meeting saat sosialisasi e-Document LKD dan BKD dosen UNIDHA

Tampilan/output dari aplikasi tersebut dapat dilihat dibawah ini sebagai interface bagi dosen agar lebih fleksibel dan friendly mengunakan aplikasi edocument LKD dan BKD, lihat gambar 8 dibawah:

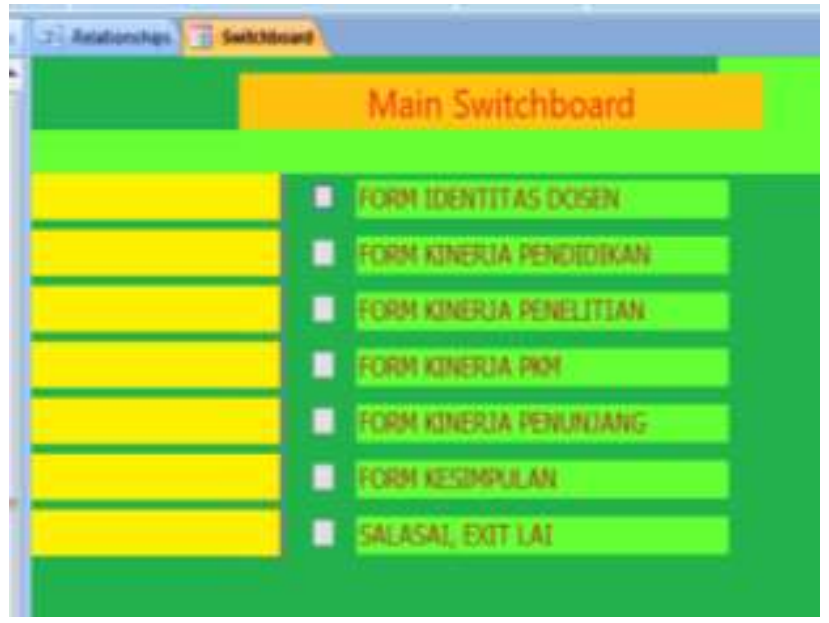

Gambar 8. Interface Aplikasi e-document

Kemudian dijelaskan juga bahwa database ini terbentuk dari table-tabel yang berelasi sehingga interface menu dapat berelasi dari table/form seperti gambar 9. Adapun table/form yang di create adalah

\begin{tabular}{|c|c|c|}
\hline \multicolumn{3}{|c|}{ IT PERGURUAN TINGGI } \\
\hline 24 & Finld Name & Data Type \\
\hline \multirow[t]{14}{*}{$\nabla \cdot$} & NIDN & Text \\
\hline & NAMA DOSEN & Text \\
\hline & KODEPT & Text \\
\hline & NAMA PT & Text \\
\hline & FAKUITAS & Text \\
\hline & PRODI & Text \\
\hline & SEMESTER & Text \\
\hline & TAHUN AKADEMIK & Text \\
\hline & SERTIFIKAT SERDOS & Attachmont \\
\hline & SK TETAP YYS/PNS & Attachment \\
\hline & SK JAFUNG & Attachment \\
\hline & SK IMPASSING DOSEN YYS & Attachment \\
\hline & IJAZAH S1 & Attachment \\
\hline & $\ldots \ldots \ldots$ & $\ldots$. \\
\hline
\end{tabular}

Gambar 9. Tabel Perguruan Tinggi

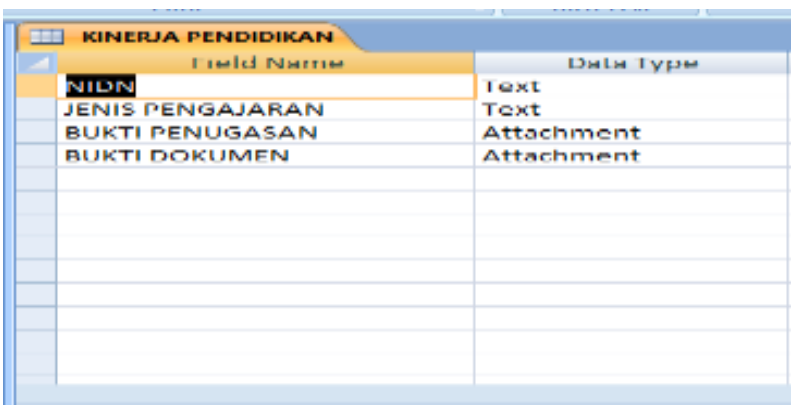

Gambar 10. Tabel Kinerja Pendidikan

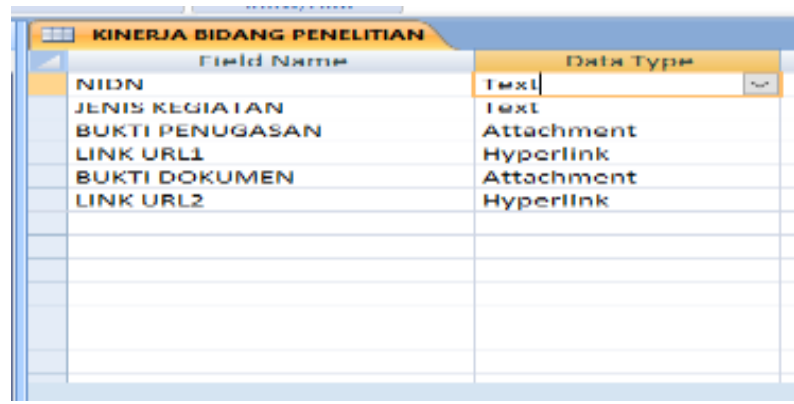

Gambar 11. Tabel Kinerja Penelitian

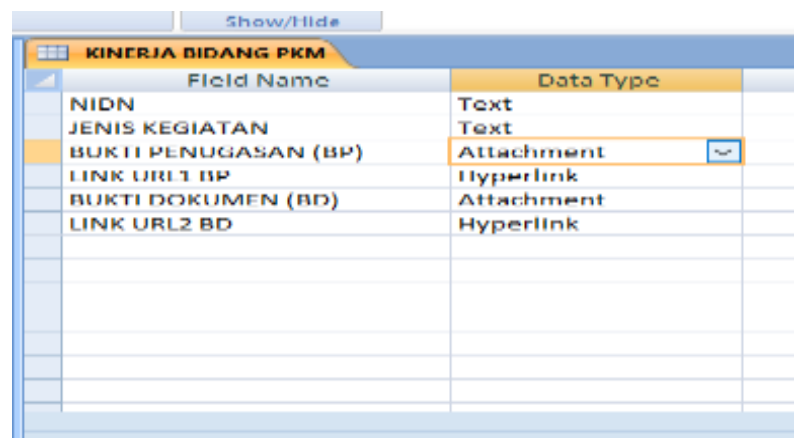

Gambar 12. Tabel Kinerja Bidang PKM 


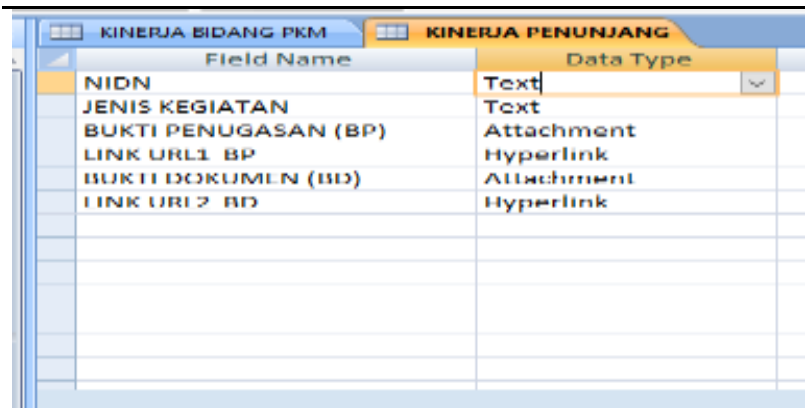

Gambar 13. Tabel Kinerja Penunjang

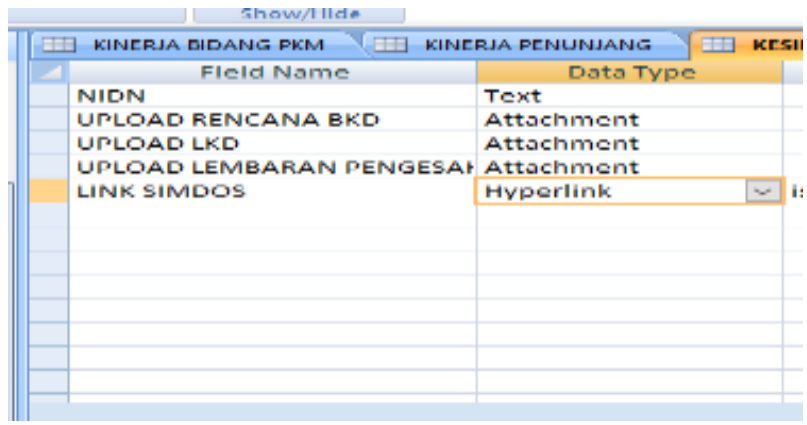

Gambar 14. Tabel Kesimpulan

Dari table-tabel diatas maka dibentuk relasi, sebelum diinput, penulis membuat design relationship, sehingga dapat dilihat pada Gambar 15 Relatioship dari table-tabel dibawah ini.

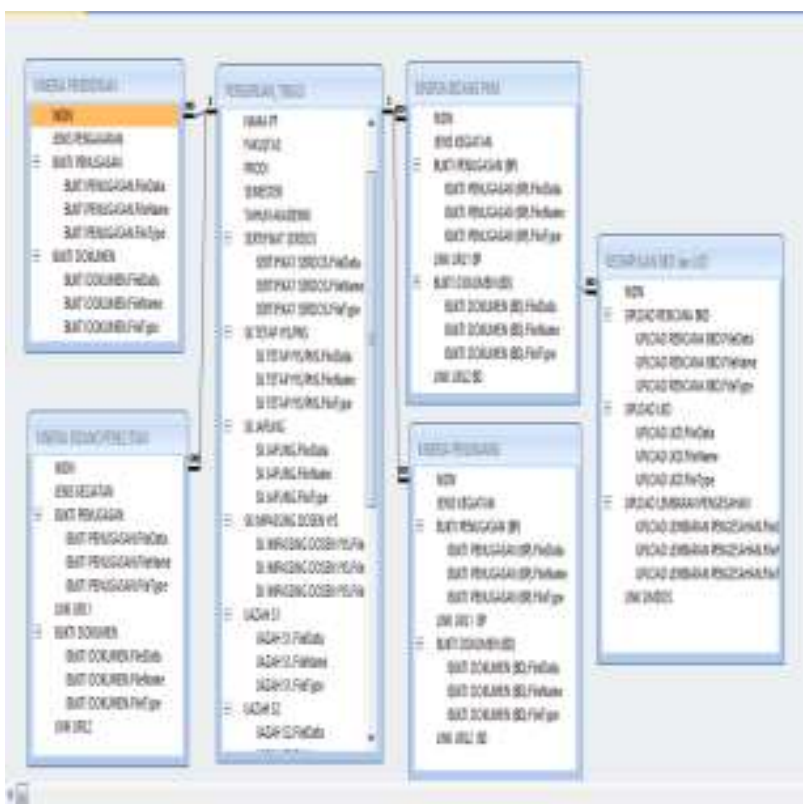

Gambar 15. Table berelasi dalam Microsoft Acces Kemudian user/dosen bisa input data/dokumen dengan meng klik form yang pada menu interface sehingga lihat pada form - form inputan yang sudah design seperti berikut :

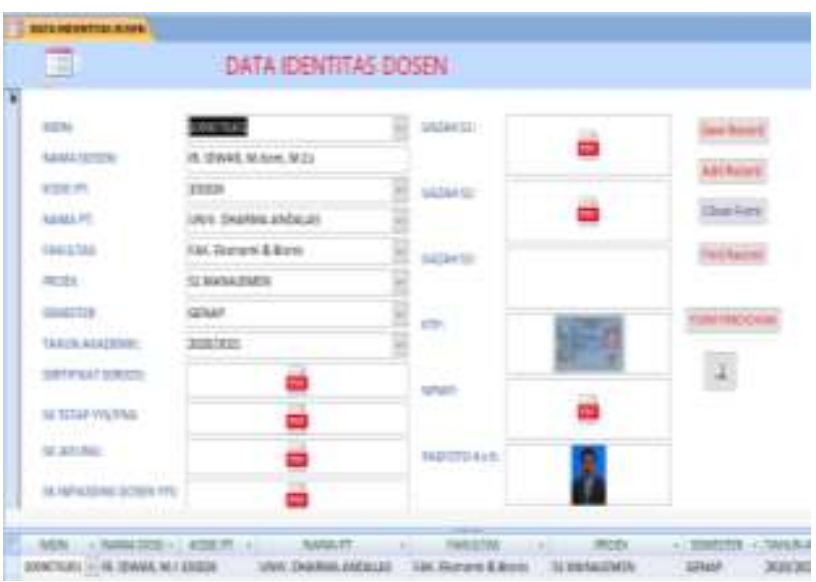

Gambar 16. Form input data indentitas Dosen

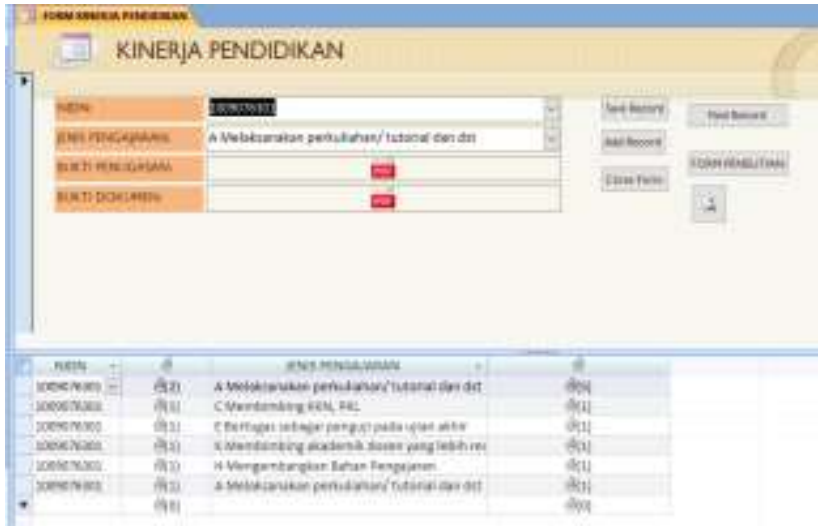

Gambar 17. Form input Kinerja Pendidikan

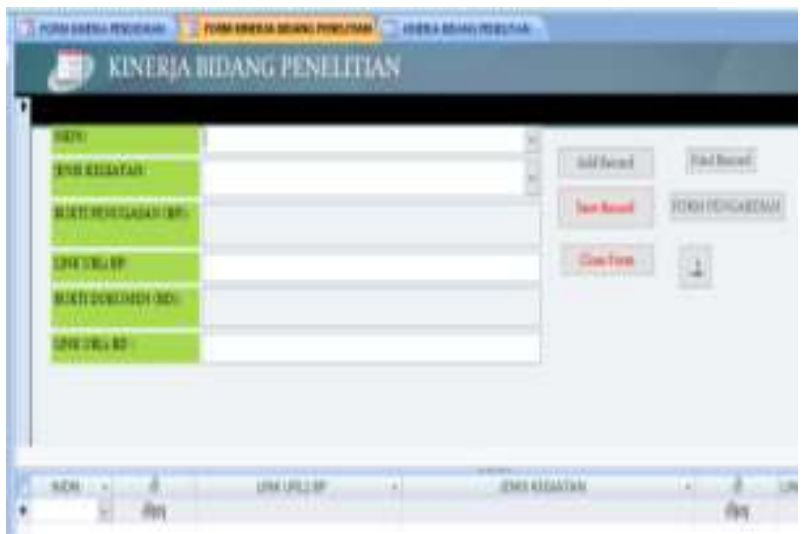

Gambar 18. Form input Kinerja Penelitian 


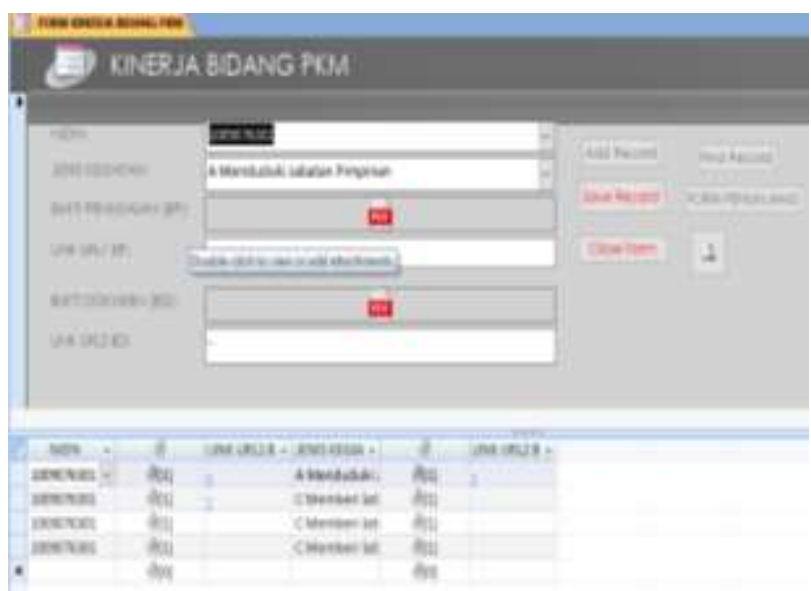

Gambar 19. Form input Kinerja PKM

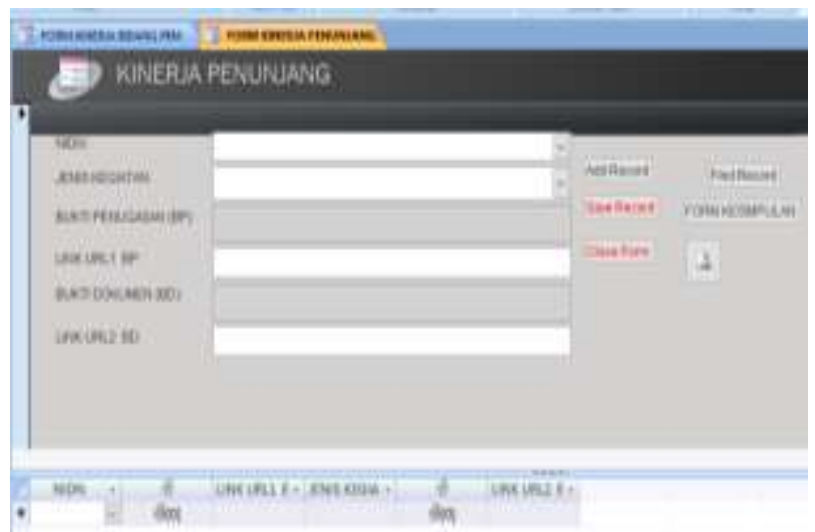

Gambar 20. Form input Kinerja Penunjang

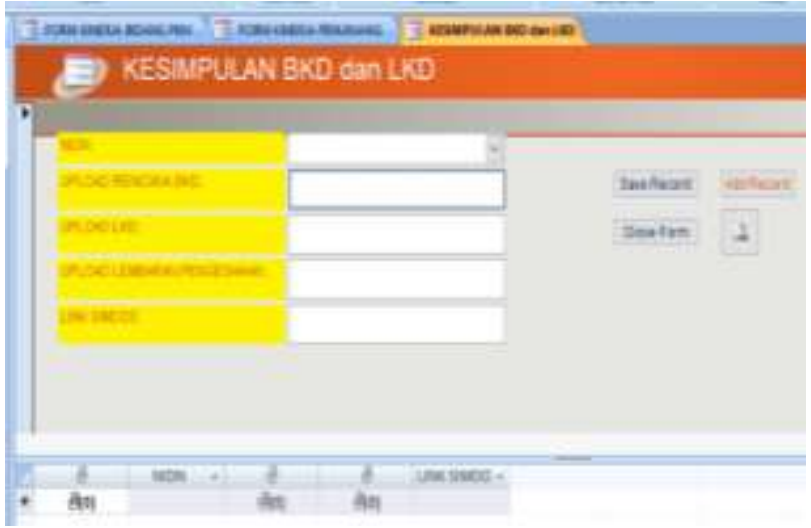

Gambar 21. Form input Kesimpulan BKD dan LKD

Setelah menginput maka user/dosen dapat melihat informasi data/dokumen yang sudah diinputkan untuk disajikan secara softcopy atau hardcopy. Dapat dilaihat pada gambar 22- 27 berikut ini :

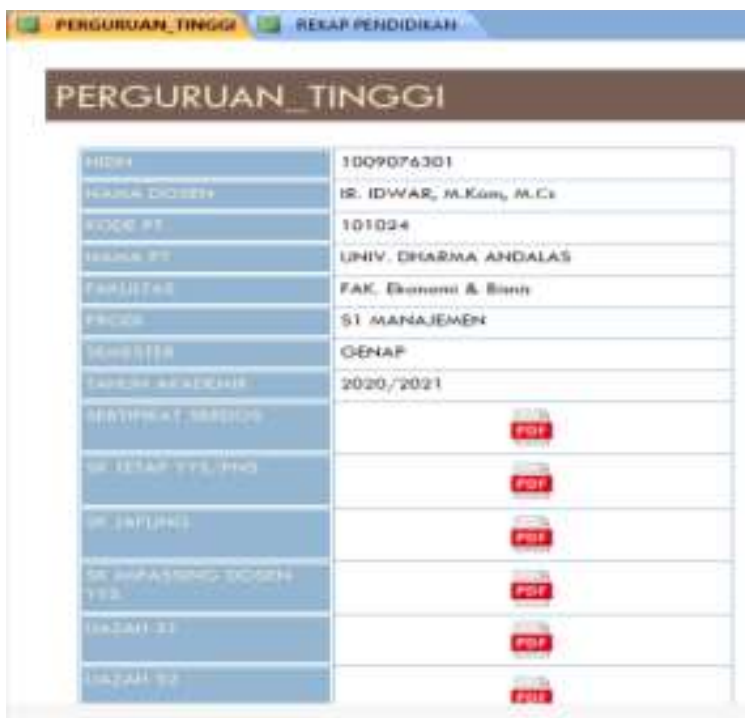

Gambar 22. Report dari table Pendidikan Tinggi

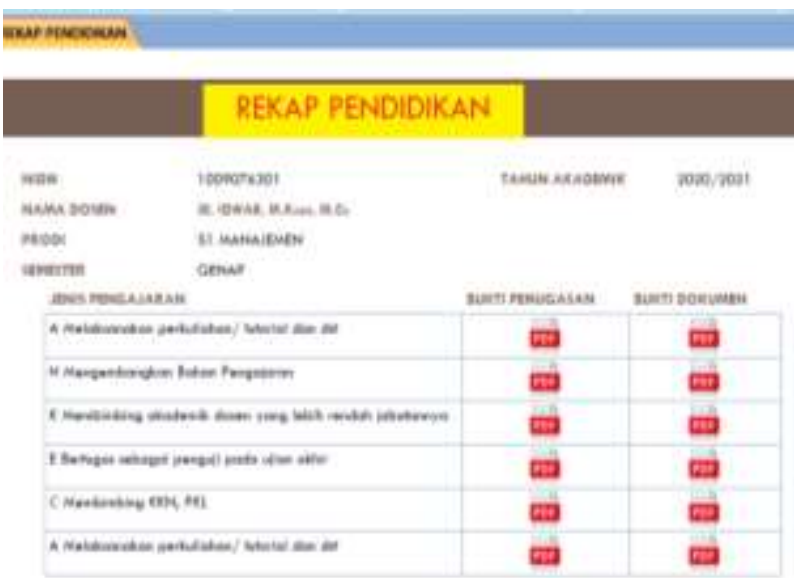

Gambar 23. Report dari table Kinerja Pendidikan

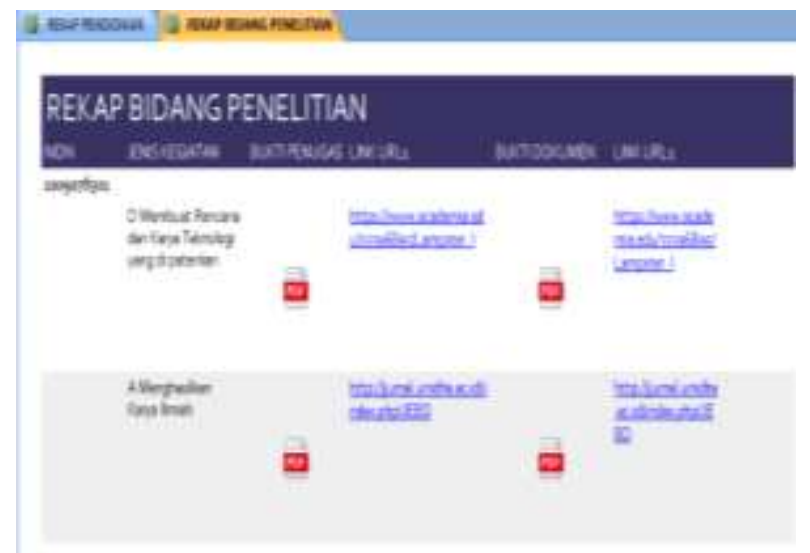

Gambar 24. Report dari table Kinerja Penelitian 


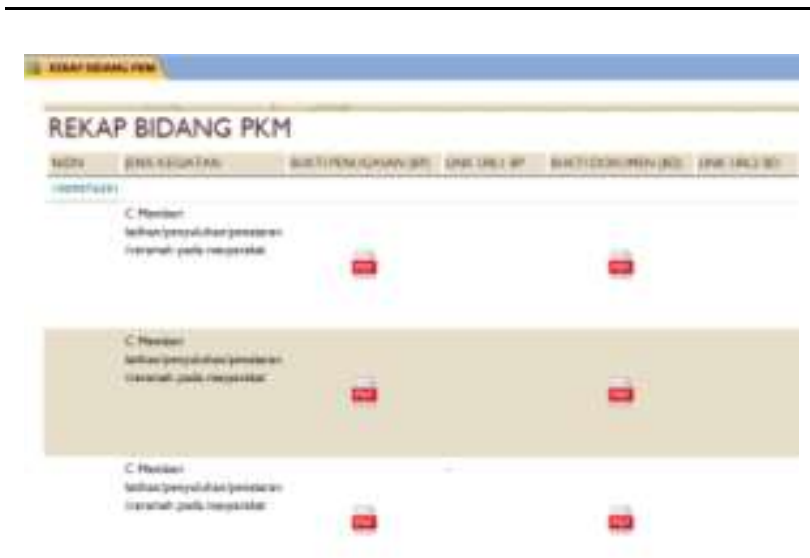

Gambar 25. Report dari table Kinerja PKM

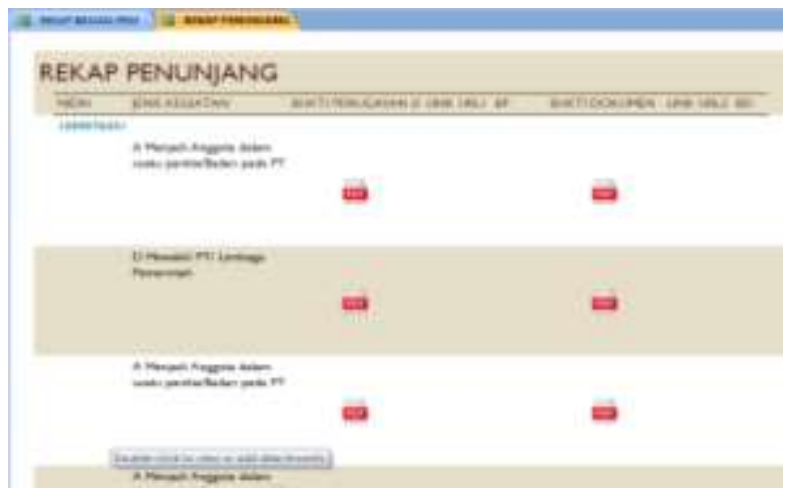

Gambar 26. Report dari table Kinerja Penunjang

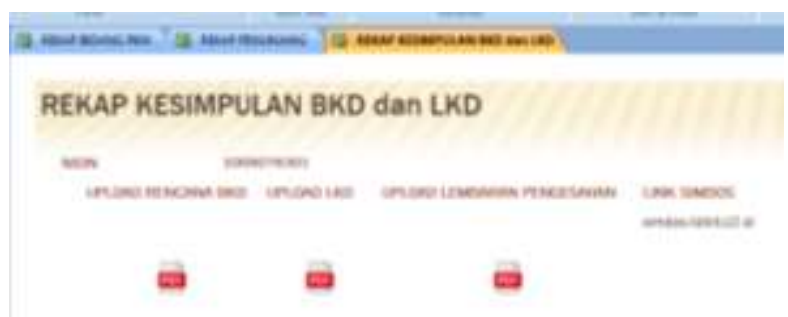

Gambar 27. Report dari table Kesimpulan

\section{KESIMPULAN}

Dari kegiatan sosialisasi ini dapat dihasilkan oleh penulis sebuah aplikasi database relasional yang diimplementasikan untuk dosen-dosen dilingkungan Universitas Dharma Andalas (UNIDHA) dengan Flatform Microsoft Access yang easy to use and friendly by user.
Selain hal diatas dosen sudah dapat menghasilkan save document digital setiap semester dan data mining e-document yang siap disajikan juga untuk menbantu input BKD dan LKD pada SISTER.

Diharapkan bagi pembaca dan penulis dapat mengembangkan aplikasi kedalam berbasis web.

\section{UCAPAN TERIMAKASIH}

Terima Kasih Rektor Universitas Dharma Andalas (UNIDHA), Prof. DR. Apt. Deddi Prima Putra, yang telah membuka kegiatan sosialisasi Edocument BKD \& LKD ini secara resmi melalui zoom meeting.

Terima juga kepada Dekan FEB Universitas Dharma Andalas (UNIDHA), Candidat Prof. Dr.Asniati, MBA,CSRA, Ak, telah mengikuti acara sosialisasi sekaligus sangat support dengan terciptanya aplikasi E-Document LKD dan BKD ini

Tak terhingga dosen-dosen UNIDHA yang mempunyai semangat tinggi dapat mengunakan aplikasi e-Document sebagai arsip database digital setiap semester yang telah dipakai semester gasal dan genap 2020/2021.

\section{REFERENSI}

Chen , 1976. The entity relationship model toward a unified view of data. ACM Trans. Database Sys., 1(1):9-36, 1976

E.F Codd, 1990, The Relational Model for database Management, Addison-Wesley publishing Company

Idwar, 2015, Pelatihan Database Relational Model Grade Penilaian Siswa/ Mahaiswa oleh Guru/Dosen pada SMTA dan PTN/PTS Di Sumatera Barat, Prosiding Pendidikan dan Teknologi Tepat Guna, PKMCSR.

Idwar, 2018, Pelatihan Database Relational Sistem Pengajian Tenaga Non Kependidikan Pada Universtas Dharma Andalas (UNIDHA) Padang, Prosiding PKMCSR 